\section{DuPont bolsters life sciences Stem cell ruling protests}

Chemical giant DuPont (Wilmington, DE) agreed last month to buy Pioneer Hi-Bred (Des Moines, IA) in a deal worth $\$ 7.7$ billion. DuPont will pay cash and stock for the remaining $80 \%$ of the world's largest seed concern it does not already own. As a result, DuPont's agriculture businesses will be worth $\$ 5$ billion-a major player in agricultural biotechnology competing directly with Monsanto (St. Louis, MO), which bought several seed companies last year (Nat. Biotechnol. 16, 497, 1998). The deal follows DuPont's announcement that it plans to issue a tracking stock for its life sciences business. Pioneer, the stock price of which jumped $40 \%$ on the day following news of a possible deal, will continue to operate under its own name but as a wholly owned subsidiary of DuPont.

\section{India faces GM cotton delay}

India's first biotechnology-related court case could delay introduction of Monsanto's (St. Louis, MO) genetically modified (GM) Bollgard cotton by a year. The Research Foundation for Science, Technology and Ecology, a nongovernmental organization in Delhi, has filed a petition alleging that trials being conducted by Maharashtra Hybrid Company (MAHYCO; Mumbai, India) are harmful to the environment and were illegally authorized by the Indian government's Department of Biotechnology. It also claims that MAHYCO, of which Monsanto owns $26 \%$, compromised biosafety guidelines by asking farmers to plant seeds before obtaining formal permission. As a result, the Department of Biotechnology has until the end of April to reply to a supreme court notice instructing them to justify the permission they gave for the field trials; MAHYCO denies all charges. Furthermore, in February, the government Review Committee for Genetic Manipulation questioned the validity of test trial data, which claimed that the GM cotton yield was $40 \%$ higher than control crop and that no pesticide was required. Before permitting large-scale field trials, the review committee asked for the trials to be repeated in 10 more locations, under independent monitoring, to clarify the amount of pesticide used and the extent of bollworm attack.

Business and Regulatory News Briefs written by Vicki Brower, Emma Dorey, Alan Dove, Jeffrey Fox, Ingeborg Fürst, KS Jayaraman, and Adam Michael.
Seven US Republican senators and 70 members of the House Pro-Life Caucus group in the US Congress protested against the February ruling by the Department of Health and Human Services (HHS; Washington, DC) that federal financing of human embryonic stem cell research is permissible under current law. The HHS, which has not responded to the latest protests, produced its ruling after numerous sessions of Congress were held from December 1998 to February 1999. At these, scientists from the National Institutes of Health (Bethesda $\mathrm{MD})$, biotechnology companies such as Geron (Menlo Park, CA) and Advanced Cell Therapies (Worcester, MA), and medical ethicists testified as to the potential benefits of stem cell research (Nat. Biotechnol. 17, 139, 1999). HHS ruled that human embryonic stem cell research is legal, but it stipulated that issues surrounding the creation and manipulation of stem cells be resolved before federal funding is released.

\section{EPA sued over Bt crops}

A coalition of environmental activists, led by Greenpeace (Washington, DC), filed a lawsuit in February to try to force the US Environmental Protection Agency (EPA; Washington, DC) to repeal its approval of Bt (Bacillus thuringiensis) transgenic crops. The plaintiffs contend that the EPA has not sufficiently studied the possible effects on the environment of the genetically modified (GM) crops produced by such companies as Monsanto (St Louis, MO) and Mycogen (San Diego, CA). Greenpeace and its supporters are particularly concerned that GM crops planted on about 20 million acres of US land in 1998 will lead to widespread insect resistance to bacterial proteins
Progeny BioVentures (Guilford, UK), a new firm created in March, aims to raise $\mathfrak{E} 110$ million (US\$176M) and start up 40 biotechnology firms over the Andrew Newland plans to assemble management teams around UK university technologies that have been selected for commercial potential. He hopes the business plans formulated will attract early-stage venture capital. Progeny has $\mathfrak{E 6 0 0 , 0 0 0}$ of its own funds. But to kick-start the scheme, the UK Department of Trade and Industry has put up $£ 400,000$, with the provinext 10 years. Managing Director from $B t$ that are also used by organic farmers as an emergency pesticide. Studies have so far failed to support the claim that GM plants will foster resistance to neighbors, and Alan Goldhamer, executive director of technical affairs for the Biotechnology Industry Organization (Washington, DC), adds that "courts have traditionally found in favor of the EPA" in similar suits. Still, Goldhamer cautions biotechnologists against complacency: "We take this as a credible suit. The [EPA] has to respond to the complaint and document its actions."

\section{Food fight in Colombia}

The United States, Canada, Australia, and several South American agriculture export nations formed a small but potent coalition that deliberately lodged a spanner in the Biosafety Protocol negotiations, held in Cartagena, Colombia, during February (Nat. Biotechnol. 17, 123, 1999). The coalition forced a stalemate because it felt the protocol-considering the impact of genetically modified organisms (GMOs) on biodiversity-would create bureaucracy likely to wreck the countries' agricultural export businesses. Although delegates from many of the 183 nations in the United Nations anticipated completing this component of the Convention on Biological Diversity, they not only left Cartagena without the expected Biosafety Protocol in hand but with none in sight. For now, the talks have been suspended and are expected to resume before May 2000. Meanwhile, US officials are saying that having failed to produce such a protocol is preferable to having completed a flawed agreement. As it stands, without a protocol, individual countries are free to set restrictions on the import of GMOs as they see fit.

\title{
New initiative to promote UK biotechnology start-ups
}

so of seeing 10 new biotechnology firms and $\mathfrak{E 3 . 2}$ million venture capital within three years.

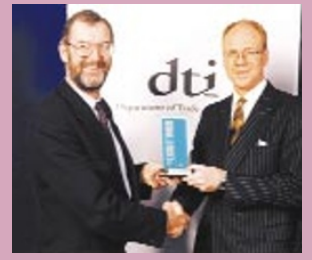

UK minister for industry, John Battle (left), with Progeny's Andrew Newland. Several venture capital firms are already backing the scheme and, according to Newland, the weight of interest-from, among others, Rothschild Asset Management (London)-helped clinch the DTI award. Progeny "is the first proactive group to set up [biotechnology] firms" in the UK and is distinctly different from and more effective than biotechnology incubators, which supply laboratory space and some business guidance only, he says. 